\title{
Application of the Analytic Hierarchy Process to Identify the Most Suitable Lessor of Freight Car Finance Leasing
}

\author{
Lei Lei ${ }^{1}$, Yin Zhou ${ }^{2}$ and Yongqing $\mathrm{Xiao}^{2}$ \\ ${ }^{1}$ Graduate School, China Academy of Railway Sciences, Beijing 100081, China; \\ ${ }^{2}$ Transportation and Economic Institute, China Academy of Railway Sciences, Beijing 100081, China
}

\begin{abstract}
Finance leasing (also "equipment leasing") saves the cost, improves the efficiency and benefit, larger the manufacture supply channels, which is an optimal solution for equipment supply with uncertain freight demand. The article collects the definitions of Finance Leasing based on the four pillars theory of finance leasing, also divides the lessors in Freight Car finance leasing into three categories according to their major business: manufacturers, banks as the representative financial institutions, firms that specialized in finance leasing. To identify the most suitable lessor for each railway department, an indicator system is built and operated by Yaahp (a software) based on Analytic Hierarchy Process.
\end{abstract}

\section{Introduction}

In recent years, a number of national policies have been made to relax the social capital investment railway options, intended to promote the reform of railway investment and financing system. According to the World Bank 2014 China Transportation Special Top 10 (Private Capital for Railway Development), to attract more private sector investment to the railway sector, the most fundamental step is to create railway markets (e.g., equipment leasing) and entities (e.g., leasing companies, railway infrastructure companies, etc.) that are profitable and financially sustainable.

Under downward pressure on China's economy, demand of coal and steel has been declined in recent years and so has the railway freight volume. With the guidance of the management principle, less cost and more efficient, the China Railway Corporation (CRC) had stored up some locomotives and freight cars before October in 2016. That month, the demand of railway traffic sharply increased mainly driven by the policy that forbidding cars overloaded running on the road, the coals supply quantities and price were shooting up. Facing this challenge, CRC has an urgent problem, the shortage of freight car. In order to improve the railway traffic volume, railway administrations carrying the major goods of coal decided to relieve some stored up freight cars and even purchased some additional to support the transport capacity. On the other hand, the decline demand for rail freight in recent years has reduced the amount of new purchasing and old repairing freight cars, which leads the general overcapacity of vehicle manufacturing and maintenance enterprises.
Financial leasing can utilizes the railway equipment manufacturing enterprises idle capacity and helps the railway operators to overcome the shortage of equipment at the same time [1]. Because mobile equipment is recognized as a financial leasing assets [2-5], the objective of this paper is to explore the suitable lessor of freight car finance leasing using analytic hierarchy process.

The rest of the paper proceeds as follows: Section 2 reviews the literature about finance leasing in China. Section 3 establishes lessors selection analysis framework, describes our methodology and applying it to the problem. We present the strategy analysis results of lessor selection in Section 4 and conclude in Section 5.

\section{Literature review of railway finance leasing}

Finance lease also known as modern leasing or equipment leasing. The definition is not unified yet [6], there is no obvious solution as to where to draw the line on a consistent basis for all countries [7]. Based on the universally recognized theory of 'four pillars of financial leasing, concerning law, accounting standards, supervision and tax policies, introduced by famous international leasing experts Sudhir P. Amembal. The definition of financing lease in China for four pillars (Table 1) focus on different parts. The Ministry of Finance pays more attention to the risk, compensation, ownership and other closely related aspects for accounting, while the Contract Law focuses on the description of the rights and obligations of both parties. The administrative organs cares similar to the Contract Law, but a bit more rigorous, and tax departments 
emphasize ownership period and others closely related to tax treatment methods. In addition, the definition of finance leasing from accounting standards is various between countries. Fortunately, Chinese Accounting Standard for Business Enterprises No. 21 - leasing, to a large extent, is reference to the International Leasing Accounting Standards IAS 17 and the lease accounting standards of other countries, such as the Unite State. [8] The finance leasing in this paper is equipment leasing, that the lessor and the lessee have a financial contract of equipment that allow the separation of ownership and use of an asset.

Table 1. Definitions about the finance leasing

\begin{tabular}{|c|c|c|}
\hline Institution & $\begin{array}{c}\text { Policy / } \\
\text { Document }\end{array}$ & Related Definition \\
\hline $\begin{array}{l}\text { The } \\
\text { Ministry of } \\
\text { Finance }\end{array}$ & $\begin{array}{l}\text { Accounting } \\
\text { Standard for } \\
\text { Business } \\
\text { Enterprises } \\
\text { No. } 21- \\
\text { leasing }\end{array}$ & $\begin{array}{l}\text { Finance lease is a lease that } \\
\text { essentially transfers all the } \\
\text { risks and rewards associated } \\
\text { with the ownership of the asset. } \\
\text { Its ownership may be or not be } \\
\text { eventually transferred. }\end{array}$ \\
\hline $\begin{array}{l}\text { Standing } \\
\text { Committee } \\
\text { of the NPC }\end{array}$ & $\begin{array}{l}\text { Contract Law } \\
\text { of the } \\
\text { People's } \\
\text { Republic of } \\
\text { China } \\
\text { (1999) }\end{array}$ & $\begin{array}{l}\text { The finance leasing contract is } \\
\text { a contract that the lessors } \\
\text { purchase the lease items from } \\
\text { sellers according to lessees' } \\
\text { target sellers and lease items, } \\
\text { provide the use right to lessees } \\
\text { and get rents paid by lessees. }\end{array}$ \\
\hline $\begin{array}{l}\text { Ministry of } \\
\text { Commerce }\end{array}$ & $\begin{array}{l}\text { Provisional } \\
\text { Measures on } \\
\text { Administratio } \\
n \text { of Domestic } \\
\text { Leasing } \\
\text { Investments of } \\
\text { Qualified } \\
\text { Foreign } \\
\text { Institutional } \\
\text { Investors } \\
\quad(2005)\end{array}$ & $\begin{array}{l}\text { The term "finance leasing } \\
\text { business" as mentioned in the } \\
\text { present Measures refers to the } \\
\text { business of the lessors leasing } \\
\text { the use right to the lessee on } \\
\text { the basis of the lessees' choice } \\
\text { of the seller and the leased } \\
\text { items, and collecting rent from } \\
\text { lessees. }\end{array}$ \\
\hline $\begin{array}{l}\text { China } \\
\text { Banking } \\
\text { Regulatory } \\
\text { Commissio } \\
\mathrm{n}\end{array}$ & $\begin{array}{l}\text { Measures for } \\
\text { the } \\
\text { Administratio } \\
n \text { of Finance } \\
\text { Leasing } \\
\text { Companies } \\
(2014)\end{array}$ & $\begin{array}{l}\text { The term "financial leasing" as } \\
\text { mentioned in the present } \\
\text { Measures means that the } \\
\text { lessors should lease items } \\
\text { obtaining from the supplier to } \\
\text { lessees according to lessees' } \\
\text { selection or requirement and } \\
\text { receive rents, all these should } \\
\text { be in accordance with the } \\
\text { contract. }\end{array}$ \\
\hline $\begin{array}{l}\text { The State } \\
\text { Administrat } \\
\text {-ion of } \\
\text { Taxation }\end{array}$ & $\begin{array}{l}\text { Notification } \\
\text { About } \\
\text { Turnover Tax } \\
\text { of Finance } \\
\text { Leasing } \\
(2000)\end{array}$ & $\begin{array}{l}\text { Finance leasing refers to the } \\
\text { equipment leasing business has } \\
\text { the nature of financing and the } \\
\text { transfer of ownership: Lessors } \\
\text { purchase equipment and lease } \\
\text { to the lessee according to the } \\
\text { lessees' required specifications, } \\
\text { models, performance and other } \\
\text { conditions. Within the contract } \\
\text { period, the ownership of the } \\
\text { equipment belongs to the } \\
\text { lessor, the lessee has only the } \\
\text { right of use. On the expiry of a } \\
\text { contract, the lessee has the } \\
\text { right to purchase the equipment } \\
\text { by the residual value to own }\end{array}$ \\
\hline
\end{tabular}

\begin{tabular}{|l|l|l|}
\hline & $\begin{array}{l}\text { the ownership of the } \\
\text { equipment. }\end{array}$ \\
\hline
\end{tabular}

Source: From the policy documents in this table.

Original in World War II, the finance lease has been studied extensively in the extant literature, but there are many puzzles that have not been solved so far. For example, the debt and lease are complementary or substitutional. On the other side, the academic communities basically reach consensus on that the finance leasing with industry bias exists, especially in the air transport and retail trade, services and public utilities. [9]

Although carried out late comparatively, Chinese finance lease is developing fast since 2010 and China has become second largest leasing market in the world. During 2009 to 2012, rate of annual growth is up to $61 \%$, and business volume reached $\$ 88.9$ billion in 2014. [7] Due to the date qualification, theoretical research lags behind the actual business in China. More quantitative academic research compared with qualitative research has been carried out there.

The financial leasing research of railway focuses primarily upon the necessity. Du Meijie (2010) compares the difficulties and costs between finance lease and bank loan. It is suggests that the finance leasing is not only a supplement of current railway financing, but also works well in optimizing the financing structure.[4] Wang Zhaocheng (2003) analyzes the current situation of railway technology and equipment leasing in China and foreign countries, has a conclusion that the modern leasing plays an important role in Chines railway development.[10] Chen Bo Shi, Ding Huiping (2006) points out there is a capital transmission relationship between the railway equipment manufacturing enterprises and rail transport enterprises. Because in current capital market environment in China, both sides are facing the same challenges, that is the single financing channels cannot meet the financing needs, which providing an opportunity for the development of finance lease. [11] Only a few qualitative research are conducted about the necessity (or called advantage). To analyze the economic feasibility of the finance lease model of railway transportation equipment, Gan Kaiyuan (2006) compares the net cash value under some assumptions. [3]

The economic feasibility of the railway finance leasing is discuss as well. The Chinese finance lease was still in its childbearing period, going through a tortuous suffering in 2008. Che Tanyan (2008) shows great concern for the finance lease whether it can catch up with the takeoff of equipment manufacturing industry, considering the difficulties of funding for leasing enterprises and the risk of outstanding payments among lessees. [12]

Involved with the specific strategies, scholars study from both the lessor perspective. Ma Yuanbing (2012) explores the regulation and risk management ability improvement for the rail leasing company.[13] He Lin (2008) analyses risk factors of the railway finance leasing and has a conclusion that the credit risk of the finance lease is higher than the bank loan for the lessee. [14] 


\section{Freight car finance leasing selection process}

The main division of the lessors based on the major business, usually divided into three categories: manufacturers, banks as the representative financial institutions and firms that specialized in finance leasing.

(1) Manufacturers

The international leasing of the railway industry started late. At present, there's few finance leasing enterprises with the background of manufacturers, and the only one named CRCC Investment \& Leasing Co., Ltd. is a wholly owned subsidiary of CRRC Corporation Limited (CRRC). Although there are railcar producing and leasing companies are multinational, such as General Electric Company (GE) and TTX Company, multinational manufacturers and lessors are less likely to enter the domestic railway finance leasing market in view of the policy "Made in China".

(2) Financial institutions represented by banks

The amount of finance leasing companies controlled effectively by the financial institutions, especially with banking background, grow up so fast. Companies including ICBC Leasing, China Development Bank Leasing, Minsheng Financial Leasing, Bank of Communications Financial Leasing provide leasing services to transportation services, such as aviation, ship and marine equipment, but there are basically no lessors engaged in freight car leasing.

These companies mainly owned by the national commercial banks, with a natural advantage in the risk prevention, are far superior to other two categories (manufacturers and specialized firms) in the lessees' risk rating, contracts management, the application of laws and regulations. Furthermore, they have more abundant human resources and dedicated departments to manage risk generally.

(3) Firms specialized in finance leasing

In fact, only a small number of specialized firms in railway equipment finance leasing exist in China.[3] They are a Sino-foreign joint venture named CHINA RAILWAY LEASING, a foreign invested enterprise named IMC-GATX FINANCIAL LEASING (SHANGHAI). Due to the incomplete rail finance leasing market, IMC-GATX China focuses on shipping leasing now, only CHINA RAILWAY LEASING is still keeping the locomotive rental business, which might benefit from its investor's major market share in railway industry, a state-owned enterprise with a long history named China Railway Materials Company. A private company named Guangzhou Zhongche Railway Vehicles Equipment had been shifted the business to the vehicle air-conditioning equipment manufacturing and was purchased by stateowned enterprise.

As a traditional and worldwide financial leasing object, railway car leasing needs different lessor around countries and companies. In North American countries, the main lessors are manufacturers, while in British they are companies controlled by the banks. [4] So it's absolutely necessary to identify the most suitable lessor for Chinese railway and find the practicable solution of cooperation between lessors and lessees.

\subsection{Lessors selection analysis framework}

From the Section 2 of paper, former literature did not so much work according to the detailed classification of railway lessors. On the one hand, it's because the finance leasing market in our country is not perfect or complete, the enterprises with high market share involved in finance leasing have not yet opened up the railway leasing market. On the other hand, the railway is a government regulation industry [15] and has the lowest degree of marketization in the field of transportation [16]. The development of finance leasing of rail is much slower than that of aviation, shipping, medical, engineering equipment and others.

In this paper, the competitiveness of railway freight car lessors stems from financing cost (FC), supporting services (SS), management capacity (MC) and four pillars theory of finance leasing (FP).( Shen Yanli, 2008 [17], Zhen Lin, 2015 [18]). Analysis framework of lessor selection is established (Fig. 1). The four pillars theory has been discussed in Section 2. The most influencing factors of financing cost include interest rate, lease term, margin and rent payment method [19]. The most influencing factors are service quality, cooperation experience, product type. And management ability are reflected as risk management and efficiency of contracts implementation.

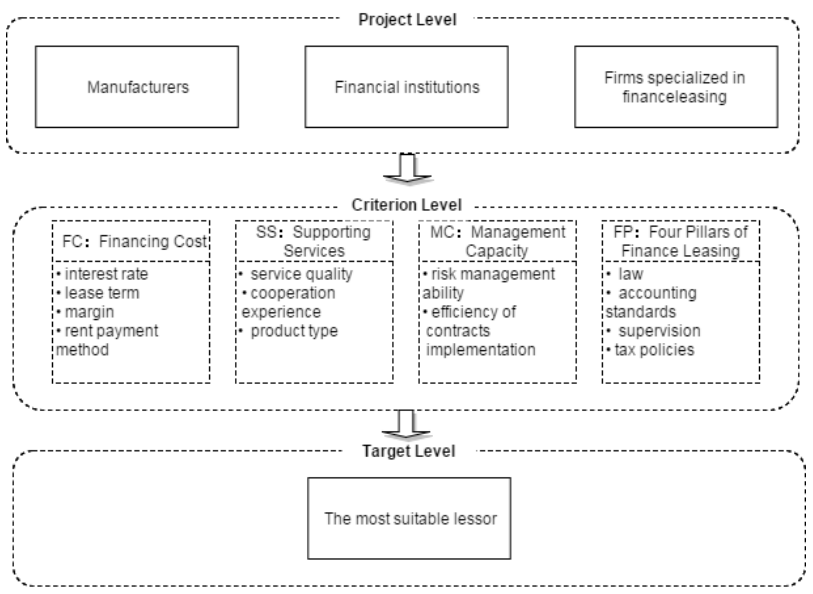

Figure 1. Analysis framework of lessors selection

\subsection{Date and method}

Delphi method, Analytic hierarchy process (AHP), DEA and Fuzzy Comprehensive Evaluation are alternative evaluation methods. Refer to Dhir S, Marinov M V, Worsley D. (2015) [20], this paper selects AHP designed by Thomas L.Saaty in the 1970s as the evaluation method. The reason for choosing AHP for application in this study was due to its primary purpose being for decision making of strategic level.

According to the general steps of AHP: First, defining the problem and desired solution. Secondly, structuring of the hierarchy. Third, construction of the pairwise 
comparison matrices. Fourth, complete all the pairwise judgments using the fundamental scale. Fifth, transferral of the judgments into matrices. Sixth, perform steps 3, 4 and 5 for all pairwise comparisons. Seventh, use the synthesis method to produce the eigenvectors and priorities for each matrix and hence calculate the final priorities. [21]

We invited twenty experts in railway management departments to do the questionnaire survey and fortunately twenty are effective questionnaires recovered. We analyze this program by Yaahp, a business software specialized for AHP method.

\subsection{Application of the analytic hierarchy process}

\subsection{1 constructing the analytic hierarchy}

The hierarchical analysis structure is the same as Fig. 1, the first layer corresponds to the project level, the second layer corresponds to the criterion level, the third layer corresponds to the target level.

\subsubsection{Weight ascertainment}

First, construct the judgment matrix. According to the commonly used $1 \sim 9$ scales of comparisons (Saaty (1999) [21], Du Dong (2008) [22]), experts compare and numerically value each comparison of criteria (see Criterion Level in Fig. 1) using questionnaire. We construct the pairwise comparison matrix by collecting the experts questionnaire. And the resulting matrix could be seen as Table 2-6.

Secondly, test consistency for each matrix through characteristic root test. Calculate characteristic root $\lambda_{\max }$ of equation ( $\mathrm{AW}=\lambda_{\max } * \mathrm{~W}, \mathrm{~A}$ and $\mathrm{W}$ are matrix), then get priorities of criteria after the normalization. More detail calculation steps can be seen in Du Dong's book (Du Dong, 2008) [22].

Table 2. Criteria 1- Pairwise Comparison Matrix

\begin{tabular}{|c|c|c|c|c|c|}
\hline $\begin{array}{c}\text { The most } \\
\begin{array}{c}\text { Suitable } \\
\text { Lessor }\end{array}\end{array}$ & FC & SS & MC & FP & $\boldsymbol{W}_{\boldsymbol{i}}$ \\
\hline FC & 1 & $1 / 3$ & $1 / 3$ & $1 / 7$ & 0.0752 \\
\hline SS & 3 & 1 & $1 / 3$ & $1 / 5$ & 0.1512 \\
\hline MC & 3 & 3 & 1 & $1 / 5$ & 0.5083 \\
\hline FP & 7 & 5 & 5 & 1 & 0.2653 \\
\hline
\end{tabular}

Note: FC is short for financing cost, SS is short for supporting services, $\mathrm{MC}$ is short for management capacity and FP is short for four pillars theory of finance leasing.

Yaahp computing result is $\lambda_{\max }=4.1981$, C.R. $($ Consistency Ratio $)=0.0742<0.10$, pass the consistence test.

According to the importance order (Table 2), judgements that $\mathrm{MC}$ is the strongest factor to identify the most suitable lessor, followed by FP, SS and FC.

Table 3. Criteria 2- Priorities of Finance Cost (FC)

\begin{tabular}{|c|c|c|c|c|c|}
\hline $\begin{array}{c}\text { Financin } \\
\text { g Cost } \\
\text { (FC) }\end{array}$ & $\begin{array}{c}\text { Margi } \\
\mathbf{n}\end{array}$ & $\begin{array}{c}\text { Rent } \\
\text { Paymen } \\
\mathbf{t} \\
\text { Method }\end{array}$ & $\begin{array}{c}\text { Leas } \\
\mathbf{e} \\
\text { Ter } \\
\mathbf{m}\end{array}$ & $\begin{array}{c}\text { Interes } \\
\mathbf{t} \text { Rate }\end{array}$ & $\boldsymbol{W}_{\boldsymbol{i}}$ \\
\hline Margin & 1 & 3 & 3 & $1 / 3$ & $\begin{array}{c}0.265 \\
3\end{array}$ \\
\hline $\begin{array}{c}\text { Rent } \\
\text { Payment } \\
\text { Method }\end{array}$ & $1 / 3$ & 1 & $1 / 3$ & $1 / 5$ & $\begin{array}{c}0.075 \\
2\end{array}$ \\
\hline $\begin{array}{c}\text { Lease } \\
\text { Term }\end{array}$ & $1 / 3$ & 3 & 1 & $1 / 3$ & $\begin{array}{c}0.151 \\
2\end{array}$ \\
\hline $\begin{array}{c}\text { Interest } \\
\text { Rate }\end{array}$ & 3 & 5 & $1 / 3$ & 1 & $\begin{array}{c}0.508 \\
3\end{array}$ \\
\hline
\end{tabular}

Yaahp computing result is $\lambda_{\max }=4.1981$, C.R. $=$ $0.0742<0.10$, pass the consistence test.

Table 4. Criteria 3-Priorities of Supporting Services (SS)

\begin{tabular}{|c|c|c|c|c|}
\hline $\begin{array}{c}\text { Supporting } \\
\text { Services (SS) }\end{array}$ & $\begin{array}{c}\text { Service } \\
\text { Quality }\end{array}$ & $\begin{array}{c}\text { Cooperation } \\
\text { Experience }\end{array}$ & $\begin{array}{c}\text { Product } \\
\text { Type }\end{array}$ & $\boldsymbol{W}_{\boldsymbol{i}}$ \\
\hline $\begin{array}{c}\text { Service } \\
\text { Quality }\end{array}$ & 1 & $1 / 3$ & 3 & 0.2583 \\
\hline $\begin{array}{c}\text { Cooperation } \\
\text { Experience }\end{array}$ & 3 & 1 & 5 & 0.637 \\
\hline Product Type & $1 / 3$ & $1 / 5$ & 1 & 0.1047 \\
\hline
\end{tabular}

Yaahp computing result is $\lambda_{\max }=3.0385$, C.R. $=0.0370$ $<0.10$, pass the consistence test.

Table 5. Criteria 4-Management Capacity (MC)

\begin{tabular}{|c|c|c|c|}
\hline $\begin{array}{c}\text { Management } \\
\text { Capacity (MC) }\end{array}$ & $\begin{array}{c}\text { Efficiency of } \\
\text { Contracts } \\
\text { Implementation }\end{array}$ & $\begin{array}{c}\text { Risk } \\
\text { Management } \\
\text { Ability }\end{array}$ & $\boldsymbol{W}_{\boldsymbol{i}}$ \\
\hline $\begin{array}{c}\text { Efficiency of } \\
\text { Contracts } \\
\text { Implementation }\end{array}$ & 1 & 7 & 0.25 \\
\hline $\begin{array}{c}\text { Risk } \\
\text { Management } \\
\text { Ability }\end{array}$ & $1 / 7$ & 1 & 0.75 \\
\hline
\end{tabular}

Yaahp computing result is $\lambda_{\max }=2.0000$, C.R. $=0.0000<0.10$, pass the consistence test.

Table 6. Criteria 5- Four Pillars of Finance Leasing (FP)

\begin{tabular}{|c|c|c|c|c|c|}
\hline $\begin{array}{c}\text { Four } \\
\text { Pillars of } \\
\text { Finance } \\
\text { Leasing } \\
\text { (FP) }\end{array}$ & $\begin{array}{c}\mathbf{L a} \\
\mathbf{w}\end{array}$ & $\begin{array}{c}\text { Tax } \\
\text { Polici } \\
\text { es }\end{array}$ & $\begin{array}{c}\text { Supervisi } \\
\text { on }\end{array}$ & $\begin{array}{c}\text { Accounti } \\
\text { ng } \\
\text { Standard } \\
\mathbf{s} \\
\end{array}$ & $W_{i}$ \\
\hline Law & 1 & 7 & 5 & 7 & $\begin{array}{c}0.647 \\
1\end{array}$ \\
\hline $\begin{array}{c}\text { Tax } \\
\text { policies }\end{array}$ & $1 / 7$ & 1 & $1 / 3$ & 3 & $\begin{array}{c}0.103 \\
2 \\
\end{array}$ \\
\hline $\begin{array}{c}\text { Supervisi } \\
\text { on }\end{array}$ & $1 / 5$ & 3 & 1 & 3 & $\begin{array}{c}0.190 \\
8 \\
\end{array}$ \\
\hline $\begin{array}{l}\text { Accountin } \\
\mathrm{g} \\
\text { Standards } \\
\end{array}$ & $1 / 7$ & $1 / 3$ & $1 / 3$ & 1 & 0.059 \\
\hline
\end{tabular}

Yaahp computing result is $\lambda_{\max }=4.2281$, C.R. $=0.0854<0.10$, pass the consistence test.

The resulting matrixes complete consistency check and each criteria's priorities $\left(W_{i}\right)$ are calculated (see Table 2-6). 


\subsubsection{Analysis and evaluation of results}

Fig. 2 depicts the final calculated priorities for the lessors produced by Yaahp. The most suitable lessor being manufacturer, followed by the financial institutions and then the specialized leasing companies, based on the AHP analysis conducted. During the selection, the lessee is most concerned about the management capacity, followed by the four pillars, supporting services and financing costs, which supports the idea that using only accounting factors to decide the lessor is imperfect

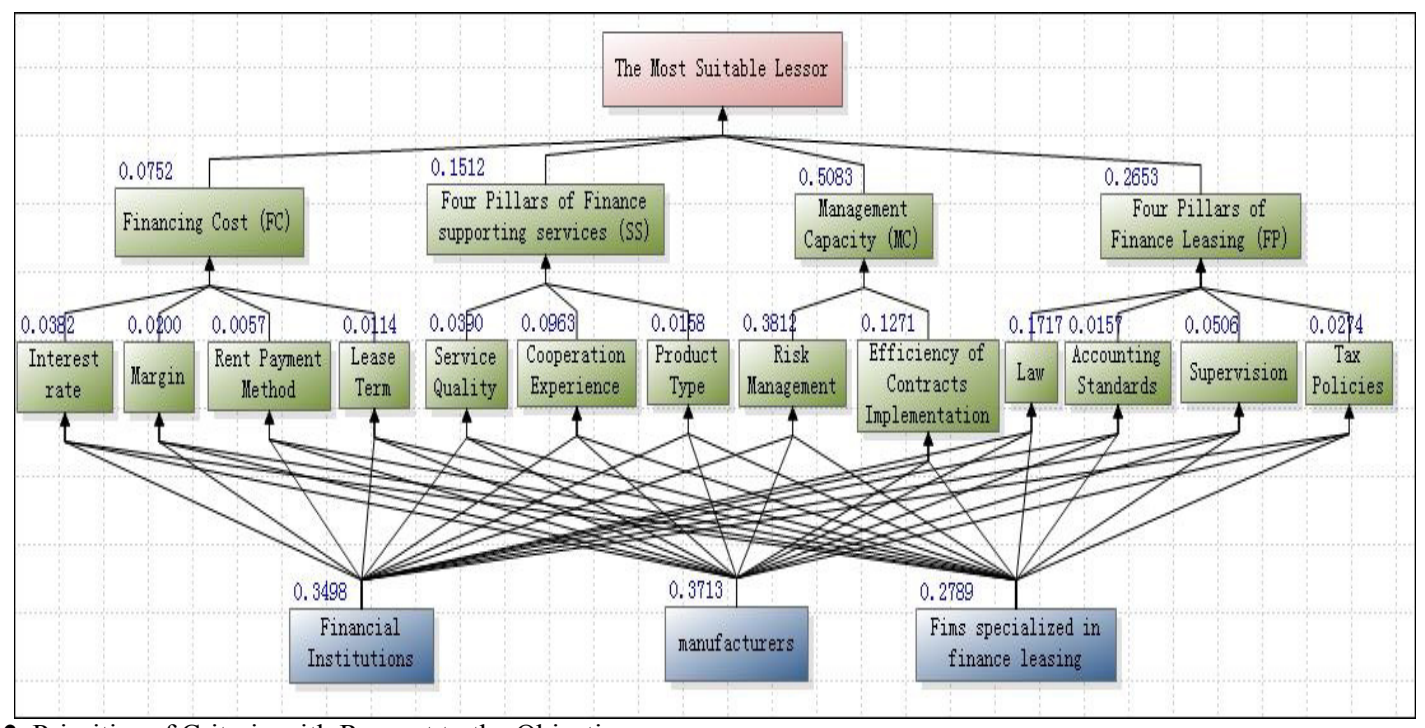

Figure 2. Priorities of Criteria with Respect to the Objective

\section{Strategy analysis of most suitable lessors}

For CRC, locomotives, freight cars and high-speed trains mainly purchased through competitive bidding procurement organized by the firm's headquarters, and rarely small part of rail equipment could be purchased independently by the railway administrations in CRC and other private companies. Different lessees with distinct rights should pick up which kind of lessors are discussed in the following section.

(1) At this stage, CRC carrying out cooperation with $\mathrm{CRCC}$ in finance lease is the best choice. According to the results of AHP analysis in Section 3, to carry out cooperation with the manufacturer contributes to lower transaction costs, which is the same finance lessor selection as North America and Europe. However, since the monopoly of both manufacturing and using rail cars in China, it would be easy to form a bilateral monopoly market if CRC were to lease freight cars and others from $\mathrm{CRCC}$, and then the rails would have to pay the excess rent. In 2006, all three British railway leasing companies were accused of over-pricing behavior by Department for Transport.

(2) For the long-term stage, the financial institutions combined with manufacturers could cooperate with CRC to develop leasing business. Manufacturers lack the experience of preventing financial risks, while finance leasing companies can prevent risk effectively, have enough funds and lower financing costs, but lack management experiences and professional persons about the leasing objects. These two sides united to form alliance is the inevitable and preferable choice for the further development of finance leasing. For more information about the benefits of this type alliance, see Chen Boshi and Ding Huiping (2006) [11].

In addition, railway enterprises with sufficient capital could establish internal finance leasing companies. A precedent as China Railway Group Limited set up an internal financial leasing company named China Railway Capital Financing Leasing in 2015 to do equipment management, equipment manufacturing transformation and upgrading, innovation of investment and finance. Besides, the financial institutions in CRC could become a shareholder of joint-stock company doing finance leasing to make full use of the resources.

(3) Under special conditions, the railway administrations or the jointly owned railway companies would cooperate with firms specialized in finance leasing as a supplement. For most of the jointly owned railways and regional railways, it is hard to issue bonds or get concessional loans. A realistic financing channel that might solve the funding problems for equipment purchase is finance lease. As specialized financial leasing agencies are highly efficient and close to the local railway companies geographically, they could response to emergency quickly which would meet local transport demand, so it's also a good choice for the railway administrations, the jointly owned railway companies and regional railways.

\section{Conclusions}

Nowadays Chinese finance leasing business develops rapidly and maturely in the fields of aviation, shipping and rail transportation, but the railway finance leasing is lagging behind other transportation mode, both in the development speed and scale. Although only a few rail car lessors are active in market currently, they are diverse 
in form, which are Sino-foreign joint ventures, stateowned enterprises and multinational companies. And banks and other financial institutions are potential lessors as well. It seems that Chinese rail car finance leasing market is a considerable potential market.

At this stage, the best cooperation is between CRC and manufacturers named CRCC. And the financial institutions combined with the manufactures will be beneficial supplements References in the long term. Considering the risk of uncertain freight demands, the cooperation of some railway administrations and the specialized firms would be another choice. If the finance leasing market improved and completed constantly, the cooperation between rails and suitable lessors could further stimulate the market power to provide excellent advisory services for rails, to improve the rails capital structure and the management level.

Only China Development Bank Leasing is a listed company, so data acquisition is difficult. It suggests that the evaluation progress could add financial indicators and the lessor's finance leasing mode could be carried out in the case of sufficient data. Furthermore, the bargaining game process of the monopoly manufacturer lessor and the lessee should be worth looking into.

\section{Acknowledgement}

Thanks to Wang Huaixiang, Song xiaoman, Zhu Jiafa, Zhang Mengdi for their invaluable guidance during the review process. We also gratefully acknowledge the financial support of Technology Research and Development Program of China Railway (Grant No. 2016F018 and No.J2016Z009). All errors are the responsibility of the authors.

\section{References}

1. B. Chen, Q. Li, H. Ding. Chinese Railways 9, 40 (2003)

2. M. Lawrence, G.O. Private Capital for Railway Development in China Transport Topics No.10. World Bank (2014)
3. K. Gan. The Innovation Research for Financing China's Railway by Financial Lease Model, 28 (2007)

4. Du Meijie. China Economic \& Trade Herald 20, 42 (2010)

5. Y. Zhang. Railway Transport and Economy 3, 5 (2008)

6. H. Zhang. Financing Leasing and its Application in the Railway, 3 (2007)

7. White Clarke Group. Global Leasing Report, 5-7 (2015)

8. L. Zhu. Commerial Accounting 1, 18 (2014)

9. Morais A I. Academia Revista Latinoamericana de Administración 26(3), 432 (2013)

10. Z. Wang. Chinese Railways 10, 11-14 (2003)

11. B. Chen, H. Ding. Review of Investment Studies 12, 25-29 (2006)

12. T. Che, W. Hu, X. Wang. Journal of Dalian Maritime University: Social Science Edition 2, 3639 (2008)

13. Y. Ma. Risk Management Study of Freight Car Lease Business for ZB Company, 27-41 (2012)

14. L. He, X. Xiao, H. Ding. Journal of Beijing Jiaotong University Social Sciences Edition 2, 78 (2008)

15. B. Chen. Research on Innovating and Realizing of Fiannce Lease in China Rail Transportation Equipment, 78 (2008)

16. X. Kang. Journal of Railway Engineering Society 8, $123(2013)$

17. Y. Shen. A Study on the Competitiveness of Chinese Financing Lease, 26-32 (2006)

18. Z. Lin, Factors Influencing Automobile Financial Leasing and Risk Control-An Empirical Study on China Automobile Leasing Marke, 41 (2015)

19. D. Han. Low Carbon World 1, 144-145 (2015)

20. Dhir S, Marinov M V, Worsley D. Case Studies on Transport Policy 4, 431-448 (2015)

21. Saaty T L. IEEE Transactions on Systems, Man, and Cybernetics SMC 15(3), 450-452 (1985)

22. D. Du, Q. Pang, Y. Wu. Modern Model of Comprehensive Evaluation and case study, (2008) 